\title{
Silicification of Garnet Peridotite Xenoliths from the Lahtojoki Kimberlite Pipe, Eastern Finland
}

\author{
Peltonen, $\mathrm{P}$.
}

Geological Survey of Finland, P.O. Box 96, FIN-02151 Espoo, FINLAND (petri.peltonen@gsf.fi)

Garnet peridotite xenoliths recoved from the diatreme facies of the Lahtojoki kimberlite pipe located within the Eastern Finland Kimberlite Province (Peltonen et al., 1998) bear evidence of metasomatic alteration processes that has never before been described from upper mantle xenoliths: all olivine and most of the orthopyroxene within the xenoliths have been replaced by normal $\alpha$ quartz and length-slow fibrous silica (i.e. quartzine), respectively. Ultramafic peridotite xenoliths have thus been transformed into metasomatic quartz-rocks containing c. $90 \mathrm{wt} . \% \mathrm{SiO}_{2}$. Perfect preservation of upper mantle textures and the original morphology of the xenoliths imply that silicification did not accompany significant changes in volume. Silicification was highly selective and clinopyroxene and garnet remained unaffected by silicifying fluids.

All olivine in all ultramafic xenoliths has been replaced by colourless translucent $\alpha$-quartz. Silica textures do not allow to judge whether silica originally deposited as crystalline quartz or as amorphous silica which later became inverted to crystalline quartz by aging (Graetsch, 1994). Most of the olivine has been replaced by elongated, worm-like, length-fast quartz grains. Featherylooking crenulation textures in turn, together with smooth bending of elongated grains, are reminiscent of soft-body or ductile deformation and give an impression that the silica originally deposited as a highly viscous precursor phase that later inverted to crystalline silica. Less common silica textures include cavity-like textures where fine grained wall-lining silica crystallised along the outer edge of former olivine grains giving way to coarser $(\varnothing \leq 100 \mathrm{~mm})$ equigranular quartz in the grain interior. Such textures probably requires that the olivine was dissolved first and that silica subsequently deposited into an empty vug. Transformation of orthopyroxene into the optically clear silica occurs gradationally through petrographically transitional stages: fresh orthopyroxene relicts are first surrounded by a "littered" dull alteration zone, then by an intermediate zone composed of $\mathrm{SiO}_{2}$-rich material with higher bierefrigence than quartz, and finally by the clear colourless platy to fibrous silica. Tiny relicts of orthopyroxene survive silicification in some grain interiors.

The heavy oxygen isotopic composition of silica (mean of $22.4 \%$, std of 1.4 , SMOW) requires that the silicification was a low-temperature process. Because the isotopic composition of the silicifying fluid is unknown, only maximum temperature can be calculated: upper limit for the silicification temperature of $130-160^{\circ} \mathrm{C}$ is obtained if the range of the isotopic composition of silica is combined with that of pure magmatic fluid and the fractionation factor of Kita et al. (1985) is applied. Any mixing of magmatic fluid with seawater or meteoric water (isotopically lighter) would result in lower calculated temperatures.

The whole rock compositions of silicified ultramafic xenoliths imply strong gain of silica, and loss of $\mathrm{Mg}, \mathrm{Fe}$, and $\mathrm{Mn}$ (Table 1). $\mathrm{SiO}_{2}$ abundances have been increased by approximately a factor of two relative to fresh garnet peridotites and exceed $90 \mathrm{wt} . \%$ in most samples (Table 1). Magnesium is the most leached element in the silicified xenoliths: $\mathrm{MgO}$ abundances have dropped to 2.27-5.66 wt. $\%$ from their original values of close to $45 \mathrm{wt} \%$. Ti, $\mathrm{Al}, \mathrm{Ni}$, and $\mathrm{Cr}$ behaved as immobile elements. 
Table 1. Major element abundances (wt.\%) of representative silicified garnet peridotite xenoliths from the Lahtojoki kimberlite pipe (Finland). Composition of an unsilicified xenolith (9.2/2) from another pipe of the Eastern Finland Kimberlite Province is shown for comparison.

\begin{tabular}{lr|rrrr}
\hline Sample\# & $9.2 / 2$ & $13-\mathrm{H}$ & $\mathrm{L}-7$ & $\mathrm{~L}-13$ & $\mathrm{~L}-36$ \\
\hline $\mathrm{SiO}_{2}$ & 43.64 & 93.46 & 87.10 & 92.97 & 93.00 \\
$\mathrm{TiO}_{2}$ & 0.01 & 0.04 & 0.12 & 0.03 & 0.02 \\
$\mathrm{Al}_{2} \mathrm{O}_{3}$ & 1.02 & 0.58 & 0.97 & 0.65 & 1.03 \\
$\mathrm{Fe}_{2} \mathrm{O}_{3}$ & 8.65 & 1.42 & 2.43 & 1.33 & 1.28 \\
$\mathrm{MgO}$ & 44.73 & 2.87 & 5.66 & 2.83 & 2.52 \\
$\mathrm{MnO}$ & 0.13 & 0.04 & 0.08 & 0.04 & 0.04 \\
$\mathrm{NiO}$ & 0.27 & 0.42 & 0.32 & 0.38 & 0.40 \\
$\mathrm{Cr}_{2} \mathrm{O}_{3}$ & 0.34 & 0.35 & 0.34 & 0.37 & 0.39 \\
$\mathrm{Na}_{2} \mathrm{O}$ & 0.12 & 0.05 & 0.18 & 0.05 & 0.05 \\
$\mathrm{CaO}$ & 0.93 & 0.72 & 2.77 & 1.26 & 1.22 \\
$\mathrm{~K}_{2} \mathrm{O}$ & 0.13 & 0.04 & 0.02 & 0.06 & 0.05 \\
$\mathrm{P}_{2} \mathrm{O}_{5}$ & 0.02 & 0.01 & 0.01 & 0.03 & 0.00 \\
$\mathrm{LOI}$ & 2.38 & 0.9 & 1.8 & 0.7 & 1.0 \\
\hline
\end{tabular}

Because similar silicification of xenoliths, as reported here, has not been observed in any other of the kimberlite pipes of the same cluster (or, to my knowledge, anywhere in the world), it is unlikely that the kimberlite magma itself could be the source for all of the fluid but some "excess" fluid is required. Although the emplacement of the kimberlite pipes at or close to the seafloor would provide sufficient fluid, it is unlikely that that the "excess" fluid was seawater because chlorine abundances of the silicified xenoliths are not elevated. Instead, I speculate that the Lahtojoki pipe is unique among discovered kimberlites worldwide in that it extruded at the base of a moderate-size lake. Following the extrusion, lake water penetrated the diatreme zone and hydrothermal circulation of mixed magmatic fluid and lake water, driven by the heat flux from the cooling kimberlite magma, leached silica from the adjacent Archaean gneisses and redeposited it within the pipe and enclosed xenoliths. Due to the limited heat capacity of the small Lahtojoki pipe, however, intense hydrothermal circulation must have been relatively short-lived, but probably the thermal gradient of the whole kimberlite province was elevated and silicification continued over considerable time due to pore fluid convection at lower temperatures.

\section{References}

Graetsch, H., 1994, Structural characteristics of opaline and microcrystalline silica minerals, in Reviews in Mineralogy, v. 29 , p. $209-232$.

Kita, I., Taguchi, S., and Matsubaya, O., 1985, Oxygen isotope fractionation between silica and water at $34-93^{\circ} \mathrm{C}$. Nature, v. 314 , p. 63-64.

Peltonen, P., Huhma, H., Tyni, M., and Shimizu, N., 1998, Garnet-peridotite xenoliths from kimberlites of Finland: nature of the continental mantle at Archaean craton - Proterozoic mobile belt transition. This volume. 